PART 3

Remembering Childhood 
Alex Drace-Francis - 9789004305809

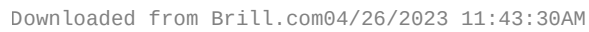
via free access 


\title{
Locating Remembrance: Regimes of Time and Cultures of Autobiography in Post-Independence Romania ${ }^{1}$
}

\author{
Alex Drace-Francis
}

Introduction: Romania as Post-Imperial Polity?

Within the classical Ottoman polity, the provinces of Moldavia and Wallachia always occupied something of a borderland position. ${ }^{2}$ When they came under Russian protection after the Treaty of Adrianople (1829), their autonomy was put on a formal footing, and modern institutions established after the 'European' model. Russia's defeat in the Crimean War led to unification (1859), to the adoption of the new name of 'Romania' (1861) and to independence under a German monarch, Karl of Hohenzollern (1878). This new kingdom more than doubled its territory and population after the First World War, with the acquisition of lands from the former Austro-Hungarian and Russian empires in the Paris Treaties of 1919-1920.

This apparently smooth state-formation process, bearing some comparison with the successful earlier unifications in Germany and Italy, has meant that historians have not generally considered Romania as a 'post-Ottoman' state. For example, the standard English-language history of modern Romania considers

1 The research for this chapter was initially undertaken in the framework of the "Regimes of Historicity" project at the Centre for Advanced Study, Sofia, in the academic year 2009-2010. I am grateful to the directors of that project, Diana Mishkova and Balázs Trencsényi, for supporting my research and to the research team as a whole for offering commentary on it. I also received invitations to present early versions of my findings at the European History Seminar, Trinity College Dublin (October 2009); at the Centre for the Study of the Balkans, Goldsmiths, London (February 2011); at the Fifth Conference of the Society for Romanian Studies, Sibiu, Romania (July 2012); and at the Central European University, Budapest (May 2013). Thanks to Graeme Murdock, Dejan Djokić, Irina Livezeanu and Constantin Iordachi respectively for affording me those opportunities, and to the audiences for their constructive comments and feedback.

2 Kemal H. Karpat and Robert W. Zens (eds), Ottoman Borderlands: Issues, Personalities, and Political Changes (Madison: University of Wisconsin Press, 2003). 
the country to have followed the 'classic' model of European state-building. ${ }^{3}$ Ottomanists have accorded little attention to the Romanian experience after $1829,{ }^{4}$ while national historians in Romania viewed Ottoman rule as a largely negative part of their country's past, rather than as part of an ongoing present. ${ }^{5}$

However, the problem of Romania's 'post-Ottomanism' can be considered not just from the point of view of diplomatic history or historiography, but also from that of contemporaneous representations of childhood and youth experience. Studying the question from this viewpoint can prove especially valuable for understanding cultural dimensions of this process of independence and decolonization. As Laurence Brockliss points out in the introduction to this volume, children were often prime targets for the inculcation of new loyalties and the development of new narratives of statehood, belonging and collective purpose. In this chapter I seek to address these topics by considering two memoirs published around the time of Romanian independence, analysis of which can afford quite significant insights for understanding the changing position of children vis-à-vis old and new social and political systems, and also the more symbolic instrumentalization of images of youth in the development of a discourse about the nation.

3 Keith Hitchins, Rumania 1866-1947 (Oxford: Clarendon Press, 1994).

4 Well-known - and otherwise meritorious - surveys of the Ottoman legacy in southeastern Europe give virtually no attention to the Romanian lands: Wayne Vucinich, "Some aspects of the Ottoman legacy," in Charles Jelavich and Barbara Jelavich (eds), The Balkans In Transition: Essays on the Development of Balkan Life and Politics Since the Eighteenth Century (Berkeley: University of California Press, 1963), 81-114; L. Carl Brown (ed.), Imperial Legacy: The Ottoman Imprint on the Balkans and the Middle. East (New York: Columbia University Press, 1996); Fikret Adanır and Suraiya Faroqhi (eds), The Ottomans and the Balkans: A Discussion of Historiography (Leiden: Brill, 2002); Tea Sindbæk and Maximilian Hartmuth (eds), Images of Imperial Legacy: Modern Discourses on the Social and Cultural Impact of Ottoman and Habsburg Rule in Southeast Europe (Münster: LIT, 2011); Frederick Anscombe, State, Faith and Nation in Ottoman and Post-Ottoman Lands (Cambridge: Cambridge University Press, 2014).

5 For critical analyses of Romanian historiography on the Ottomans see e.g. Mirela-Luminiţa Murgescu, "Turcii otomani în manualele romaneşti de istorie din secolul al xıx-lea," Caietele laboratorului de studii otomane, 1, 1990, 257-273; Lucian Boia, History and Myth in Romanian Consciousness, translated by J.C. Brown (Budapest: Central European University Press, 2001), 155-160; Silvana Rachieru, "Romanian national histories after 1990: Between Description and Analysis," Romanian Journal for Society and Politics, 5 (1), 2003, 249-262; ead., "The Turks Were not as Bad as Written in History Text Books': Acknowledging an Ottoman Legacy in present-day Romania," in Raymond Detrez and Barbara Segaert (eds), Europe and the Historical Legacies in the Balkans (Brussels: Peter Lang, 2008), 111-120. 
The texts in question are the letters of a Wallachian boyar and diplomat, Ion Ghica (1816-1897), and the childhood recollections of a Moldavian peasant, priest and schoolteacher, Ion Creangă (1839-1889). Ghica's and Creangă's memoirs were published almost simultaneously in the same leading Romanian literary journal in the late 1870 ond early 1880 s. They were also both subsequently published in book form and became classics of Romanian literature. Despite, or perhaps even because of this, they have been rather neglected by historians, either as symptoms of or as reflections on social change. ${ }^{6}$ On one level, the case study here focuses on certain technical aspects of the construction of childhood and place through literary evocation, as a common feature of nineteenthcentury commemorative practices, albeit in a lesser-known tradition. They may be considered, then, as a local variation on what has been described in other contexts as the "battle for childhood"; or the more general rise of "cultures of autobiography" in nineteenth-century Europe and the Middle East. ${ }^{7}$ In this light, Ghica's and Creangă's memoirs exemplify a process of producing symbolic narratives of individuals confronting cultural change, a procedure which has been well established in the light of other cases as a characteristic and significant part of nation-building strategies in modernizing and newly independent states. ${ }^{8}$

On another level, the analysis attempted here seeks to engage with a broader interest not just in different types of historical source, but also in how they configure a conception of modernity, through the production of "regimes of historicity." In particular, recollections of personal pasts provided a locus for considering the condition of 'pre-statehood' (figured as a world affected by institutional intrusions to a much lesser degree, or in a disorderly and violent fashion), while also

6 They are occasionally drawn upon by historians in a rather informal way, for local color: see e.g. Neagu Djuvara, Le pays roumain entre Orient et Occident: Les principautés danubiennes au début du xixe siècle (Paris: Orientalistes de France, 1989). For an idea of their place in literary history, see George Călinescu, History of Romanian Literature, translated by Leon Leviţchi (Milan: Nagard, 1988).

7 Andrew Wachtel, The Battle for Childhood: Creation of a Russian Myth (Stanford, CA: Stanford University Press, 1990); Benjamin Fortna, "Education and Autobiography at the End of the Ottoman Empire," Die Welt des Islams 41 (1), 2001, 1-31. See also the chapters by Wirtz and Köksal in this volume.

8 See e.g. Dipesh Chakrabarty, "Postcoloniality and the Artifice of History: Who Speaks for Indian Pasts?" Representations, 37, 1992, 1-26; Javed Majeed, Autobiography, Travel and Postnational Identity: Gandhi, Nehru and Iqbal: Narratives of Selfhood in Gandhi, Nehru and Iqbal (Basingstoke: Palgrave, 2007).

9 Diana Mishkova, Balázs Trencsényi and Marja Jalava (eds), Regimes of Historicity in Southeastern and Northern Europe, 189o-1945 (Basingstoke: Palgrave, 2014); cf. Maria Todorova (ed.), Balkan Identities: Nation and Memory (London: Hurst, 2004). 
functioning as a vehicle for commentary on the experience of encounter with changing institutions, such as the family, the church, the school and the army, as well as with the broader social and material environment.

\section{From Childhood to Statehood}

While childhood was of course understood in Romanian discourse as the origin point of individuals' personal journeys, it also, interestingly, formed part of a series of tropes representing the transition to nationhood, appearing frequently as a metaphor for the nation in broader public discourse at the time of Romanian independence. One of the most important liberal journals of the 1848 generation called itself "The Romanian infant" [Pruncul român]; at around the same time, a portrayal of 'the infant Liberty' as a symbol of the nascent new polity was used in cultural propaganda efforts to win sympathy in France and other western countries..$^{10}$ One of the pioneers of a new national literature in Romania, Ion Heliade Rădulescu, referred to Romanian literature as being "still in swaddling clothes."11 According to the Transylvanian Timotei Cipariu, the Romanian nation was "a poor infant, abandoned in the middle of the road."12 "The Romanian's heart," said the newspaper Popolul suveran, was "young and full of love."13

What is more, the image of a youthful Romania-whether as innocent and childlike or impatient for adulthood - evolved in juxtaposition with the symbolism associated with other nations (Figure 8.1): France, for instance, was often referred to as "the elder sister" [la søur aînée] of Romania, within a broader web of metaphors about the "European family."14 The Ottoman Empire, in contrast, was proverbially "old" and "sick."15

10 See Angela Jianu, A Circle of Friends: Romanian Revolutionaries and Political Exile (Leiden: Brill, 2011).

11 Ion Heliade Rădulescu, "Chemare către folos, facere de bine şi glorie," [1843] in id., Opere, 1, edited by Dumitru Popovici (Bucharest: Fundaţia Regală pentru Literatură şi Artă, 1939-1943), 452.

12 In the paper Învăţătorul poporului in 1848, cited by Nicolae Iorga, Istoria presei româneşti (Bucureşti: Sindicatul ziariştilor, 1925), 92.

13 "Patrie, naţionalitate, România," Popolul suveran, 1 (3), 28 June/1o July 1848, in Cornelia Bodea (ed.), 1848 la români, 2 (Bucharest: Editura ştiinţifică şi enciclopedică, $1982), 698$.

14 On the 'little/elder sister' trope, see Doina Harsanyi and Nicolas Harsanyi, "The Discreet Charm of the Little Sister: France and Romania," East European Quarterly, 28 (2), 1994, 183-192; on the trope of the 'European family', see Alex Drace-Francis, The Making of Modern Romanian Culture (London: I.B. Tauris, 2006), 36, 98, 99n.7, 199.

15 The famous trope of the Ottoman Empire as a 'sick man' is commonly attributed to Tsar Nicholas I, but was part of a much older tradtion: see A.A. Livingston, "Some Early Italian 


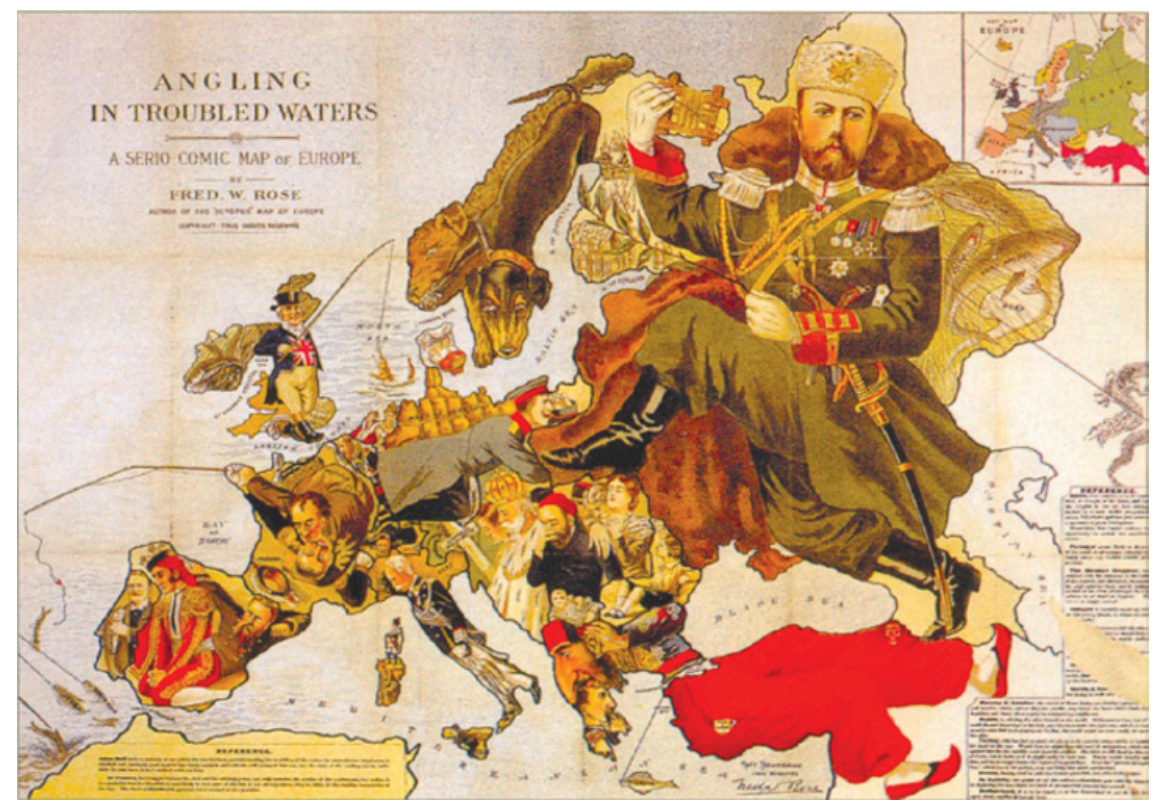

FIGURE 8.1 Fred W. Rose, Angling in Troubled Waters: A Serio-Comic Map of Europe (1899). Note how the 'young' state of Romania is figured as a child among European states.

In the light of these generalized and almost universally deployed tropes of infancy and temporal acceleration which posited a 'junior' relation with modernity and the West, studying contemporaries' recollections of youth assumes a particular significance. Some authors sought to conjure a narrative of growth and progress, distancing the new national culture from the older Ottoman order. This is particularly clear in the memoir of Ghica, who placed the Ottoman world of the 1820 in explicit contrast with the scientific, modern achievements of the new national dispensation. In other instances, such as that of Creangă, the effect is different. His memoir was partly a regional ethnography, as he proudly evokes the customs of the community in which he grew up. But it also records the drama - and to some extent the trauma-faced by a naïve male youth when coming into contact with the new national institutions of church, army and school as part of his journey into a still uncertain modernity. In both these cases, childhood is not simply recollected, but more

Parallels to the Locution "The Sick Man of the East," PMLA, 25, 3, 1910, 459-485. See also Aslı Çırakman, From the "Terror of the World" to the "Sick Man of Europe": European Images of Ottoman Empire and Society from the Sixteenth Century to the Nineteenth (New York: Peter Lang, 2002). 
complexly configured in such a way as to produce an implicit localization of social relations in time and space, both on the level of personal and subjective identity and on that of the public identity of the new state.

\section{Ion Ghica}

Ion Ghica (Figure 8.2) was born in Bucharest in 1816 into one of Wallachia's senior boyar families. His father was a noted member of one of the Ottoman 'Phanariot' families, Christians of the Fener district of Istanbul who formed a subset of the imperial bureaucracy responsible for various aspects of ecclesiastical, fiscal and regional government; while his mother descended from the native nobility of Wallachia. This type of intermarriage was typical of the symbiotic relationship of the two groups. ${ }^{16}$

After the outbreak of the Greek Revolt in 1821 and the demise of the 'Phanariot' regime, Ion Ghica's uncle, Grigore Ghica IV (1755-1834), was appointed Prince of Wallachia. Ghica junior was enrolled in the Saint Sava High School in Bucharest, a newly-established 'modern' public institution. He was subsequently sent to Paris where, along with an education in engineering and mathematics, he got wind of liberal political ideas and made contact with like-minded Romanians from other provinces, particularly Moldavia, where he took up a teaching post at the Academy at Iaşi from 1840-1843. He participated in the 1848 revolution in Wallachia, and attained high office several times during Romania's road to independence, acting as Prime Minister in 1866-1867 and $1870-1871$, and Romanian ambassador to London from 1881-1889. He was also at various times President of the Romanian Academy and Director of the National Theatre. Interestingly, however, he did not break his ties with the suzerain polity until relatively late, and for five years in the 1850 os occupied the Ottoman office of Bey of the island of Samos (1854-1859), an experience which forms the subject of a few episodes in his Romanian-language memoirs. In this light he might be considered as part of the 'post-Phanariot' community, which, as Christine Philliou has recently shown, did not automatically disappear after 1821 but continued to play a role in Ottoman governance through to the middle of the nineteenth century. ${ }^{17}$

16 On the 'Phanariot' families and their role in the history of Wallachia and Moldavia, see e.g. Vlad Georgescu, The Romanians: A History, translated by A. Bley Vroman (London: I.B. Tauris, 1991), 73-74.

17 Christine M. Philliou, Biography of an Empire: Governing Ottomans in an Age of Revolution (Berkeley: University of California Press, 2011). 


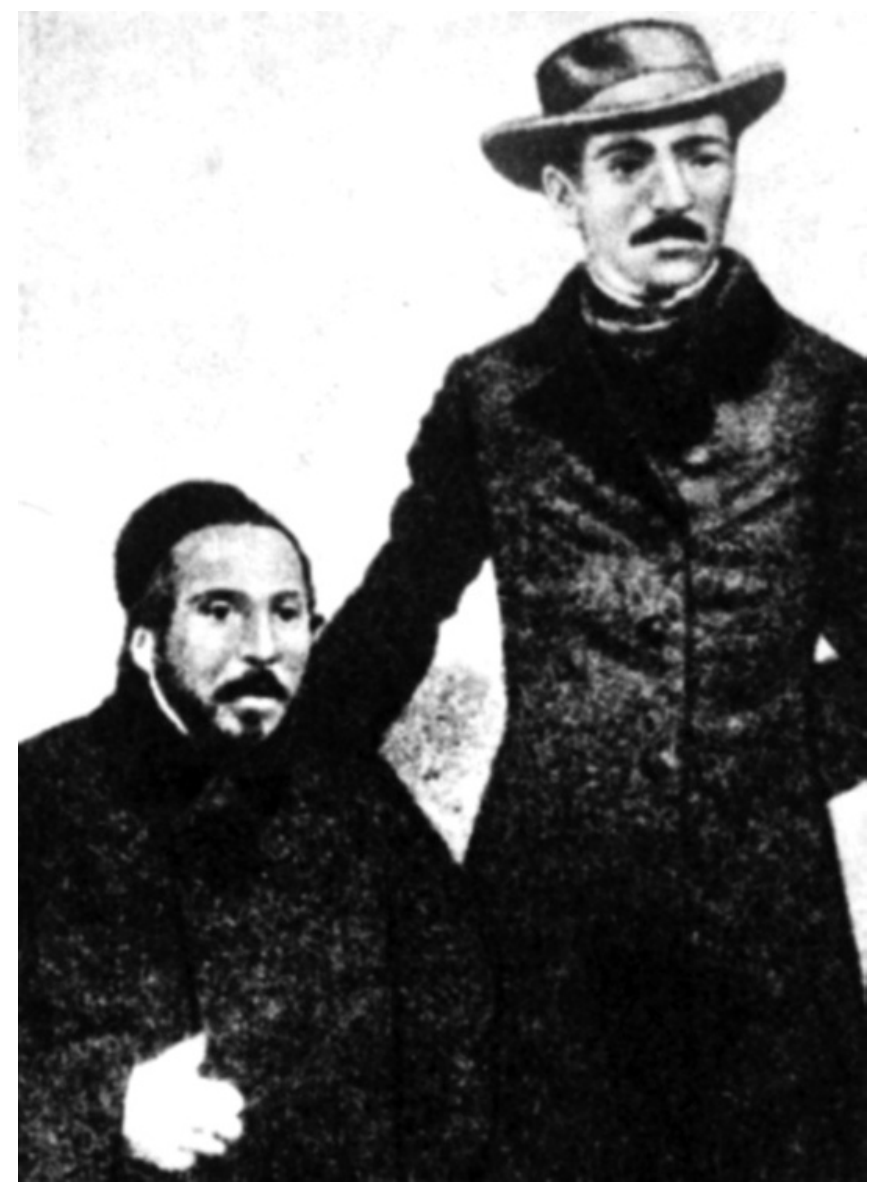

FIGURE 8.2 Ion Ghica and Vasile Alecsandri in Istanbul, 1855.

In the first phase of his career, Ghica produced a number of informative works, including brochures on economic matters such as the customs union between Moldavia and Wallachia, the adoption of modern weights and measures, political projects and survey reports on the situation of the Principalities. ${ }^{18}$ But he also experimented with literary genres, including theatre and fiction. ${ }^{19}$

18 See e.g. G. Chainoi [an anagrammatic pseudonym], Dernière occupation des Principautés Danubiennes (Paris: Librairie Militaire de J. Dumaine, 1853); Ion Ghica, Reorganisarea României (Bucharest: Stefan Rassidescu, 1861); id., Ajutorul comerciantului (Bucharest: Socec, 1873).

19 Ion Ghica, Documente literare inedite (Bucharest: Editura de stat pentru literatură şi artă, 1959); Ştefan Cazimir (ed.), Pionierii romanului romînesc (Bucharest: Editura pentru 
His best-known works, published late in life, are Convorbiri economice [Conversations on Economics] (1865-1876), Scrisori către Vasile Alecsandri [Letters to Vasile Alecsandri] (1878-1886) and Amintiri din pribegie [Recollections from Exile] (1889). ${ }^{20}$ They were typically serialized in periodicals before being issued as separate works in imposing volumes. As their titles suggest, Ghica's 'Conversations,' 'Letters,' and 'Recollections' adapt the genres of memoir and epistolary dialogue to provide perspectives on contemporary and historical Romania. They are very much 'stories' rather than 'history';21 nor are they straightforward autobiographies, insofar as they do not furnish a continuous life story and Ghica is actually quite sparse with intimate details of his personal milieu. They nevertheless constitute one of the most extensive contemporary attempts to account for Romania's social, cultural and political transformation, its 'coming of age,' adopting a series of unusual perspectives on this process.

\section{'Things of Which I Had No Idea'}

An example from Convorbiri economice may serve to illustrate this point. This work, divided into nine parts, consists mainly of standard essays on political and economic issues: the industrial development of Bucharest, the working man, cattle-raising. the decline of the great landowners. In part seven, however, Ghica has recourse to a more sophisticated framework. This section, entitled "Three Years in Romania, or the Correspondence of the Honourable Bob Dowley," deploys the trope of the fictional foreign observer, whose unfamiliarity with local customs provides a pretext for a detailed description of them, in this case to several addressees based in England. ${ }^{22}$ Ghica purports to

literatură, 1962), 3-23. Cf. Teodor Vârgolici, Aspecte ale romanului românesc (Bucharest: Eminescu 1985), 31-34, 96.

20 In the critical edition of Ion Ghica, Opere, in six volumes, edited by Ion Roman (Bucharest: Editura pentru Literatură, 1967-1988): 1 for Scrisori, 2 for Convorbiri economice. Elena Piru, "Bucureştii din vremea lui Caragea în evocarea lui Ion Ghica," Studii şi cercetări de istorie literară şi folclor, 8 (3-4), 1959, 455-467 studies Ghica's memoirs against other historical documents of the early nineteenth century. Some extracts from Convorbiri economice were included in the collection Doreen Warriner (ed.) Contrasts in Emerging Societies. Readings in the Social and Economic History of South-Eastern Europe in the Nineteenth Century (London: Athlone Press, 1965), 156-158, 164-166, 188-191, translated by E.D. Tappe. Reinhart Koselleck, Futures Past: On the Semantics of Historical Time, translated by Keith Tribe (Cambridge, MA: MIT Press, 1985) sees 'stories' [Geschichten] as a mode of historical discourse superseded by the more professional 'history' [Geschichte]. 
be translating these letters, which contain "things of which I had no idea"; the enterprise "has neither the approval, nor the sympathy of the government."23

Of particular interest here are the "regimes" of time and space forged by the fictional "Dowley". ${ }^{24}$ The very first letter enables Ghica- under the guise of his English epistolary alter ego - to paint a tableau of Bucharest as a classic "city of contrasts":

The town in which I find myself bears no resemblance to any you may have visited on your numerous travels. Imagine a population of a hundred and fifty thousand souls spread out over a plain which would easily hold over a million inhabitants. The houses, scattered about randomly, look like the stones cast long ago by the legendary Cadmus. ${ }^{25}$ Could this town somehow be destined one day to become a great and worldrenowned capital; is this why it has taken over so much land? He who lives long, will live to see! For the time being Bucharest has a primitive air. In the mahallas, most houses are of a single story! Here and there a taller one can be espied, its white tin roof peeking through the trees, like the beak of a chicken breaking through the eggshell to come out into the light. The spaces between them are taken up with wasteland, ramshackle buildings or pits. To give you an idea, I should say that a few paces up the road from my lodgings is the Princely Palace, which, with its garden, courtyards and guards house, takes up about a hundred yards of frontage on the main street; but beyond it lies a vacant lot of about twice the length.

Travellers as a Trope in Romanian Cultural Tradition," in Corinne Fowler, Charles Forsdick and Ludmilla Kostova (eds), Travel and Ethics: Theory and Practice (Abingdon: Routledge, 2013), 183-203.

23 Ghica, Opere, 2, 283-284. Using internal evidence, Ion Roman (textual notes on pages $543^{-550}$ ) has established that this part of Ghica's work was composed in $1875^{-1876}$. Curiously, a real English travel book with exactly the same title as Ghica's fictional satire appeared a few years later: see James William Ozanne, Three years in Roumania (London: Chapman and Hall, 1878).

24 The concept of 'regimes' governing perception was developed by the film theorist Christian Metz, Le signifiant imaginaire: psychanalyse et cinéma (Paris: Union générale d'éditions, 1977), and popularized in English-language scholarship by Martin Jay, "Scopic regimes of modernity," in Hal Foster (ed.), Vision and Visuality (Seattle: Bay Press, 1988), 3-23. François Hartog, Régimes d'historicité: Présentisme et expériences du temps (Paris: Seuil, 2003), applied it to theories of history; cf. Mishkova et al. (eds), Regimes of Historicity.

25 Cadmus was a legendary Phoenician prince who cast stones among the Spartoi, a race of armed men, causing them to to fall down. 
A huge courtyard, of around ten acres, in the back of which there is a ruined house, said to have belonged some years ago to a great boyar.

Through the windows of my living room, between the houses and over the eaves, a few miles distant, the eye espies a monastery, which has been patched up and transformed into the summer residence of the Prince Hohenzollern. The streets are narrow and winding. It will evidently take much time before they assume a more regular direction and a less disagreeable appearance. ${ }^{26}$

Bucharest (Figure 8.3) is somehow both enormous and unworthy; immeasurably ancient, but also behind the times. And while it may one day become "a great and world renowned capital," any chance of it "assuming a more regular direction" will clearly "take much time." Specifically, the trick of perspective afforded by the trope of the foreign traveller provides a characteristic view of Romanian society between old and new, between disorder and order.

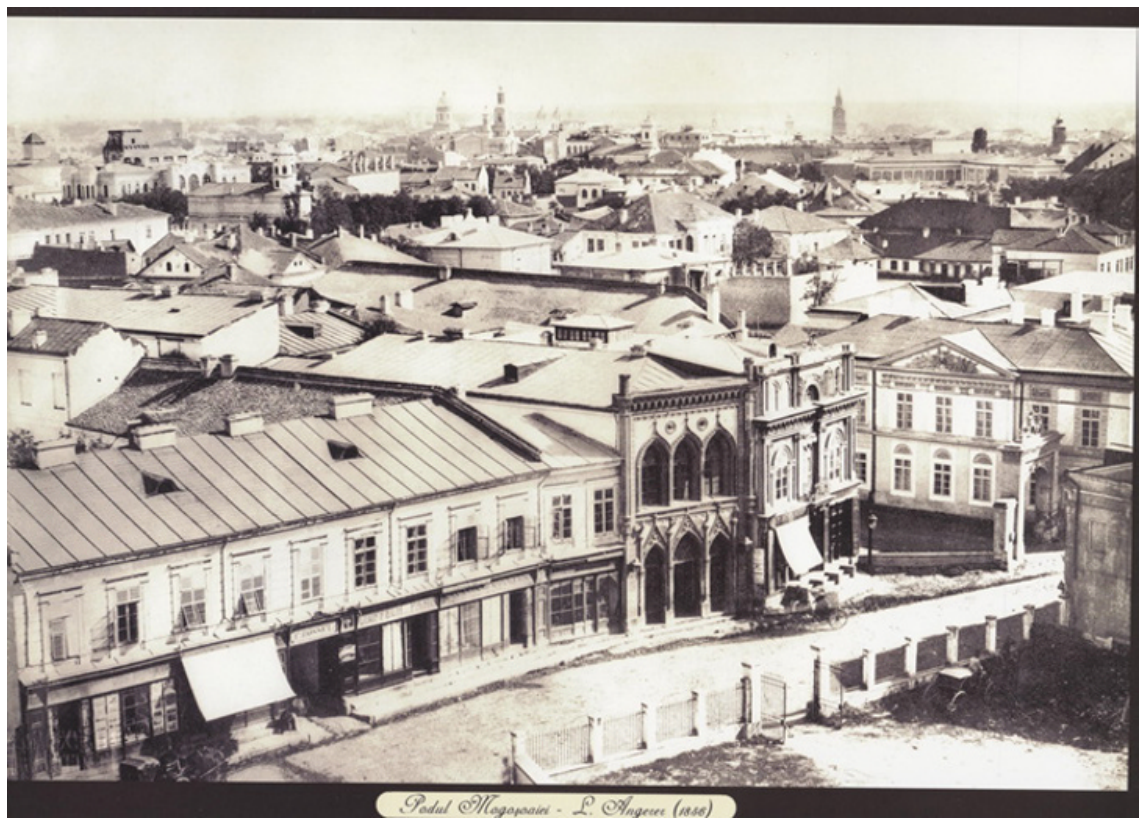

FIGURE 8.3 Rooftop view of Bucharest, 1856 (Photograph, Ludwig Angerer).

26 Ghica, Opere, 2, 285-286. 


\section{A Grand and Luminous Century above All Others}

"Three Years in Romania" is effectively a work where techniques are tried out. In Letters to Vasile Alecsandri, Ghica expands the frame, offering a retrospect on the modernization of Romania during the author's lifetime, and he showcases the success of the country in transforming itself from divided and benighted 'oriental' provinces to a modern national state. The tone is celebratory:

When I was starting to acquire an understanding of what went on in the world, a new century had entered into the course of time; the nineteenth century, a grand and luminous century above all others, destined to transfigure earthly affairs, from the East to the West. A century which brought with it a completely new civilization, undreamt of and unthought of by previous times; a civilization emerging from the scientific discoveries of human genius, which furnished the oceans, seas and rivers with steamboats; endowed the continents with railroads, lit up the world with gas and the spark of electricity; presented us with the gifts of telegraphy, telephony and photography; transformed all arts and crafts through mechanization and chemistry; multiplied production a hundred and a thousand fold; lifted up mankind from slavery and oppression, to equality and liberty; and saw new states such as Greece, Belgium, Romania, Serbia and Bulgaria reborn as if from ashes. ${ }^{27}$

The vocabulary of change deployed here shifts back and forth between 'positivist' causalities (science, mechanization) and 'providentialist' metaphor (transfiguration, rebirth). Ghica assures his correspondent that "there is no country in the world that has progressed as much as ours in such a short time" and that "nobody has the right to impede humanity's progress, which derives from man's physical and moral nature." ${ }^{28}$ At the same time, his experience, including his own personal transition to adulthood, is situated in terms of a geopolitical-but also sensorial-space. At the beginning of the nineteenth century, when the country was still under Ottoman rule,

[t]he beilic $^{29}$ on the left bank of the river Dâmboviţă at Jicniţă, and the beilik by St. Vineri Church at Iaşi were Ottoman barracks. Most of the left bank of the Danube, extending out several kilometres from the river

\footnotetext{
27 Ghica, Opere, 1, 111.

28 Ibid., 125 .

29 In Romanian, a 'beilic' denoted a lodge or barracks used to host Ottoman dignitaries visiting the Principalities.
} 
itself, was a raya [circumscription] of the fortresses of Brăilă, Giurgevo, Turnu, Kalafat and other fortified positions. From that time, some riverside villages retain the names Vizir, Mola-Braim, Mola-Scorţariu, Muftiu, Nazâru and others. These villages were under the immediate protection of Turkish overlords from the fortresses; neither the owners, nor the princely authority dared to set foot on these lands, extensive domains which today are tenanted out at yearly rents of several hundred thousand lei each, such as the estates of Brăilă and Giurgiu, the great estate of Princess Ipsilanti, or Paraipanu son of Arsake, and many others which their owners had abandoned or sold for a pittance, as well as the lakes, reed plantations and island-forests from which the Romanians could reap no profit and left to the Turks. ${ }^{30}$

The imperfection and cruelty of the Ottoman regime's juridical system is argued by reference to spatial practices: horse-thieves and murderers were "sent to Telega, Slănic, or Ocnele-Mari, or cast into some abandoned mine"; pickpockets, on the other hand, were "brought into the marketplace to be lashed on the back"; in the same locality sinful women would be exhibited "tied to a post, their heads shaven"; boyars' sons would be invited to coffee, "in the room of the cămăraş, the tufecci-başa or the baş-ciohodar, and a few switch-blows applied to the soles of their feet, prior to exile in a monastery"31

All this is being recollected by Ghica in serene old age, together with his friend, on a winter country evening "sitting on chairs by the fireside, with the snow hitting the window panes, and sweet and luminous flames before us." ${ }^{32}$ This intimate present-day position of warm and sheltered comfort becomes the vantage point from which the penal vicissitudes of the Old Regime are not only recollected, but also pushed firmly back into the past by being represented as arbitrary and violent.

\section{Spaces of Remembrance}

Many of Ghica's twenty or so Letters trace changes in schooling, travel, domestic architecture and civil and political arrangements since the 1810s. Others furnish biographical portraits of illustrious or curious figures, be they Romanian national writers, notable bandits or 'haiducs' like Tunsu and Jianu, or the English adventurer and pamphleteer David Urquhart. ${ }^{33}$ Many of them open

\footnotetext{
30 Ghica, Opere, 1, 112 .

31 Ibid., 116.

32 Ibid., 126.

33 On Ghica's relations with Urquhart see Cornelia Bodea, "David Urquhart, the Principalities and the Romanian National Movement," Nouvelles études d'histoire, 7, 1985, 207-230.
} 
with the author picturing himself in a given situation or unusual ocular/sensory perspective-not so much sites of memory as of remembrance. ${ }^{34}$ The device also acts as a bridge between the private, interior world of individual experience and the social recollection of the history of an institution and its collectivity, still symbolized by individual, localized stories.

For example, on October 25, 1886, Ghica wrote to Alecsandri, from the comfort of a London club, recalling the time, over fifty years before, when

coming out of school, I had set off on the way home, taking the little lane which began at the gate of the 'St. Sava' College, between Petrescu's house and the house with a porch belonging to the Greek abbot of the monastery, and ended at the corner where the boulevard met with Academy Street, where on one side, on the right, stood Dobrotineanu's house, and on the other, that of the spahi. The school gate was a few steps away from the church door, roughly where Lazăr's statue has been erected. There the apple-sellers and fruiterers used to set up stall, with their baskets and tables.

A great oik of a student, large as an ox, had knocked down a weak and pale boy, pushing him to the ground and pummelling him with his fists. ${ }^{35}$

Ghica goes on to explain that the David who has been thumped in this way by the schoolboy Goliath — he uses just this analogy—was none other than Nicolae Bălcescu (1819-1853), later to become a liberal politician and historian, a tireless fighter for Romanian rights who died prematurely and romantically of consumption in Sicily, leaving a famous work of history, The Romanians under Prince Michael the Brave, to be published posthumously. One dimension of the parable is obvious: small, frail individuals fall victim to school bullies, but nevertheless learn to fight back, just as - the reader can easily infer-small nations do. At another level, however, the effect of Ghica's narrative comes from it being embedded in sensory evocation of the historical topography of Old Bucharest (Figure 8.4), where Greek churchmen ("the abbot") and Ottoman soldiers ("the spahi") lived cheek by jowl with

34 Glossing Ghica, Valeriu Cristea, Spaţiul literaturii (Bucharest: Cartea Românească, 1979), 230-231, writes of 'spaces conducive to remembrance.' Seymour Chatman, Narrative Structure in Fiction and Film (Ithaca, NJ: Cornell University Press, 1978), 96ff, distinguishes between 'story space' (where the narrator is situated) and 'discourse space' (where the action takes place). Cf. Sabine Buchholz and Manfred, "Space in Narrative," in David Herman, Manfred Jahn and Marie-Laure Ryan (eds), Routledge Encyclopedia of Narrative Theory (London: Routledge, 2005), 551-555. 


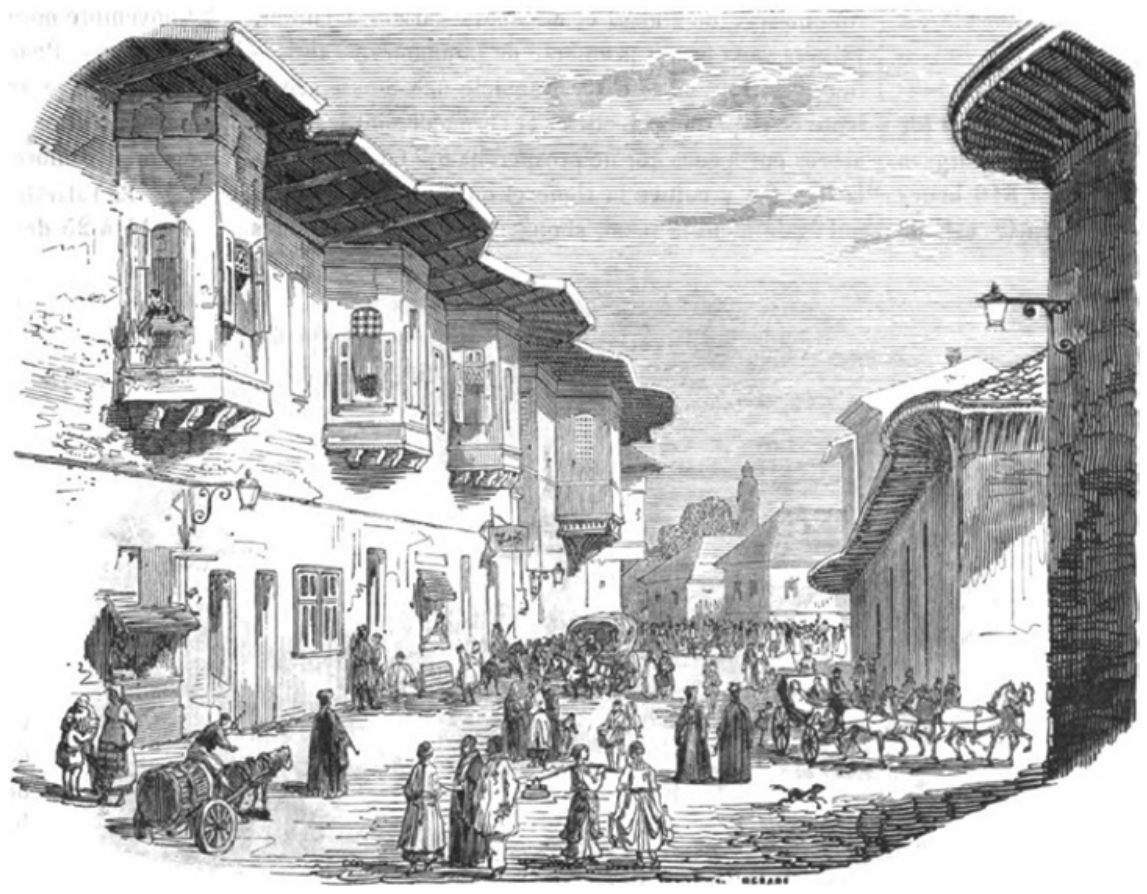

FIGU RE 8.4 Charles Doussault, Bucharest Street Scene, 1841

Romanians ("Petrescu"). And at yet another, these narrow streets with closed-in vistas, metonymic of the past, are placed in implicit opposition to the urban landscape of the modern 188os, with its statue of "Lazăr," (Figure 8.5) the teacher from Transylvania who had pioneered Romanianlanguage schooling in the 1810 s, now commemorated in the modern way, in marble, at the corner of modern, perpendicular boulevards, in a city with an Academy. ${ }^{36}$

\section{Ion Creangă}

On the surface, Ion Creangă (1839-1889) seems to be a completely different kind of writer from Ion Ghica. ${ }^{37} \mathrm{He}$ was born in Moldavia, not Wallachia; in

36 Some details on the activity of Gheorghe Lazăr (1779-1823) in Drace-Francis, Making, $5^{0-} 5^{2}$, 101. The statue in question, erected in 1886 , is still standing today outside the University of Bucharest.

37 There is a dearth of recent scholarship in English on Creangă. Among older works, Călinescu, History, 403-415, and R. Loring Taylor, "Romanian Folklore and Ion Creangă's 


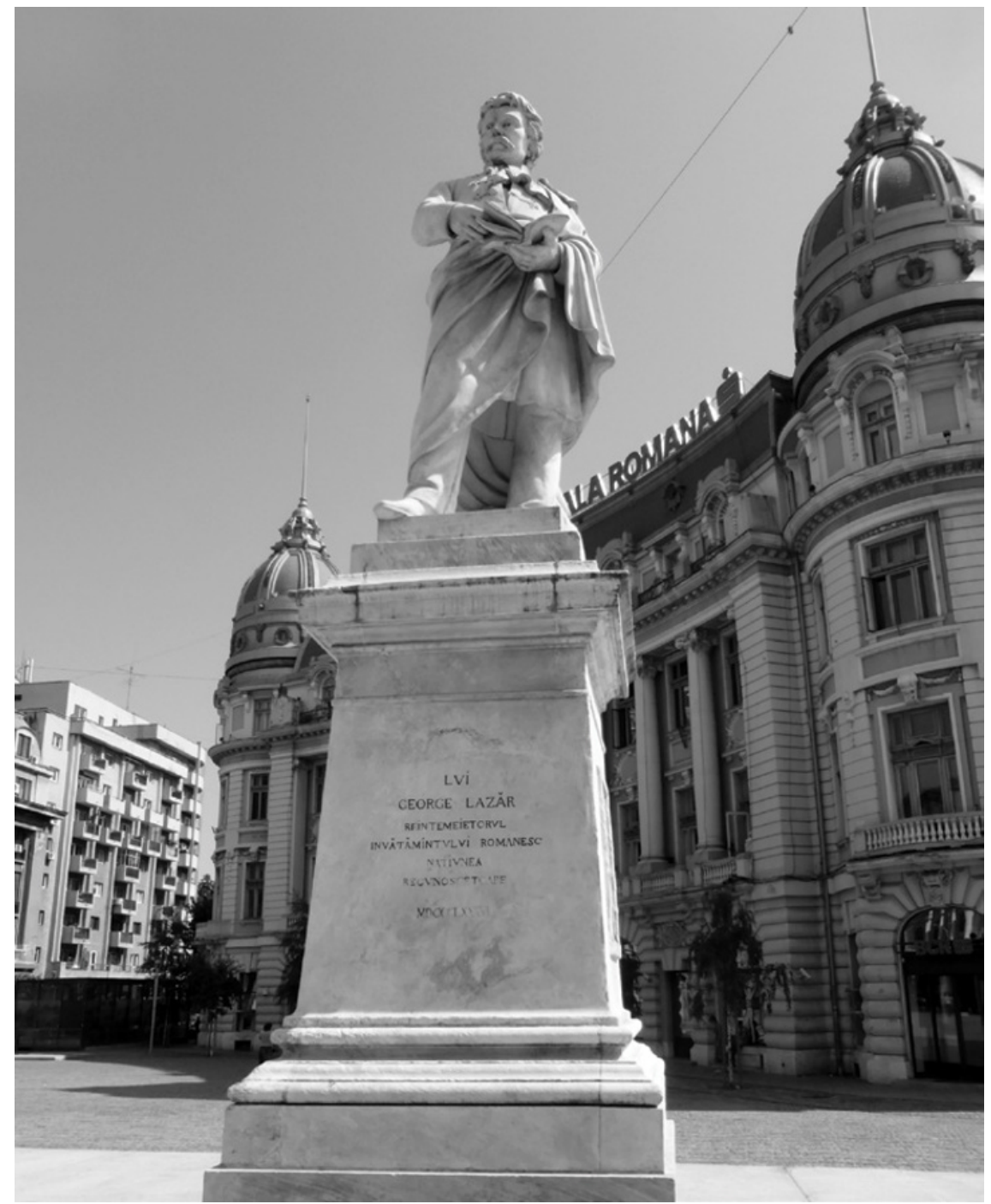

FIGURE 8.5 Statue of George Lazar, Bucharest, erected 1886. Author's photograph.

a peasant village, not in the city; and a generation after Ghica. He had little interest in science, and neither reached high office nor travelled either to the West or the East. His main education was in schools and seminaries in or near his village, located in Neamţ county, near the Carpathian Mountains bordering on Transylvania; and subsequently in Iaşi, where he arrived just as

Recollections of Childhood," Children's Literature, 4, 1975, 70-79, provide biographicalcritical perspectives. 


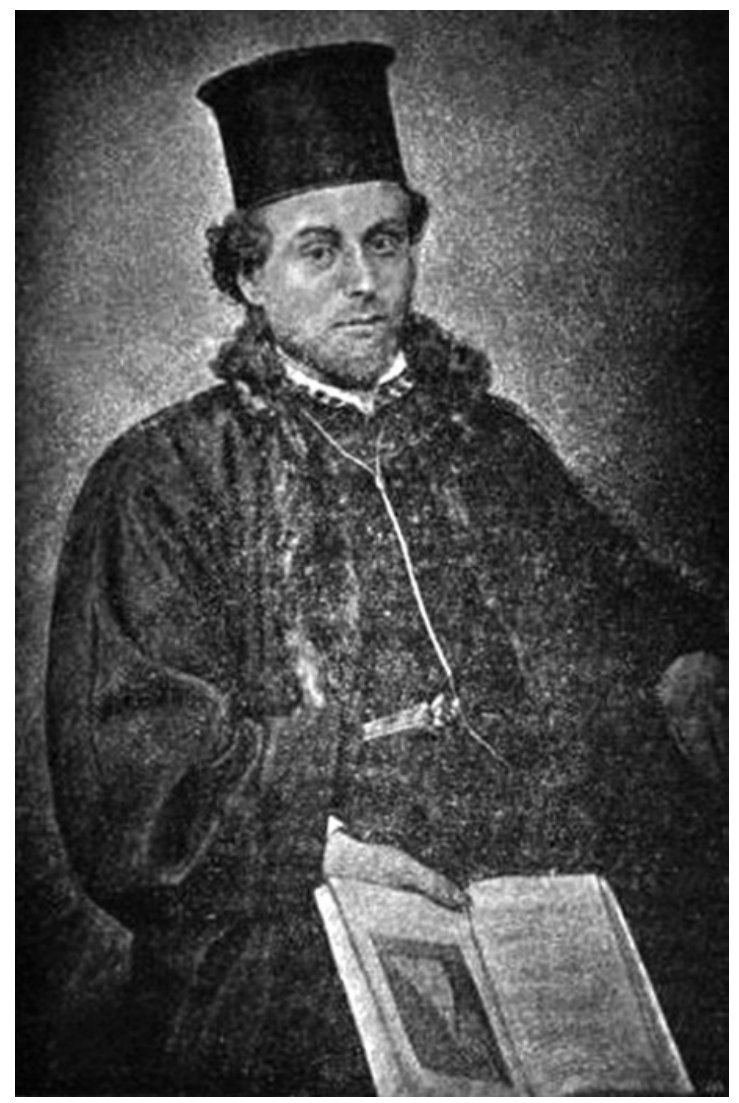

FIGURE 8.6 Ion Creangă in deacon's robes (from Şezătoarea: Revistă pentru literatură si tradiţiuni populare, $6-7,1901,120)$.

the city was losing its status as capital of Moldavia on account of the Union of the Principalities at the end of the 1850s. A man of uneven temperament, he served as deacon to various churches in Iaşi (Figure 8.6), and subsequently as schoolteacher; but in both these capacities he attracted the opprobrium of the authorities for his unorthodox behaviour. His marriage to a priest's daughter was unhappy, and he divorced in 1867-a further badge of dishonour for a would-be candidate for holy orders. Soon afterwards he was divested of his clerical duties and resigned himself to running a tobacco warehouse, while cohabiting with an older woman and an extensive menagerie of cats.

Creangă was rescued from this unpropitious predicament when he came into contact with the influential Junimea [Youth] literary society, effectively a 


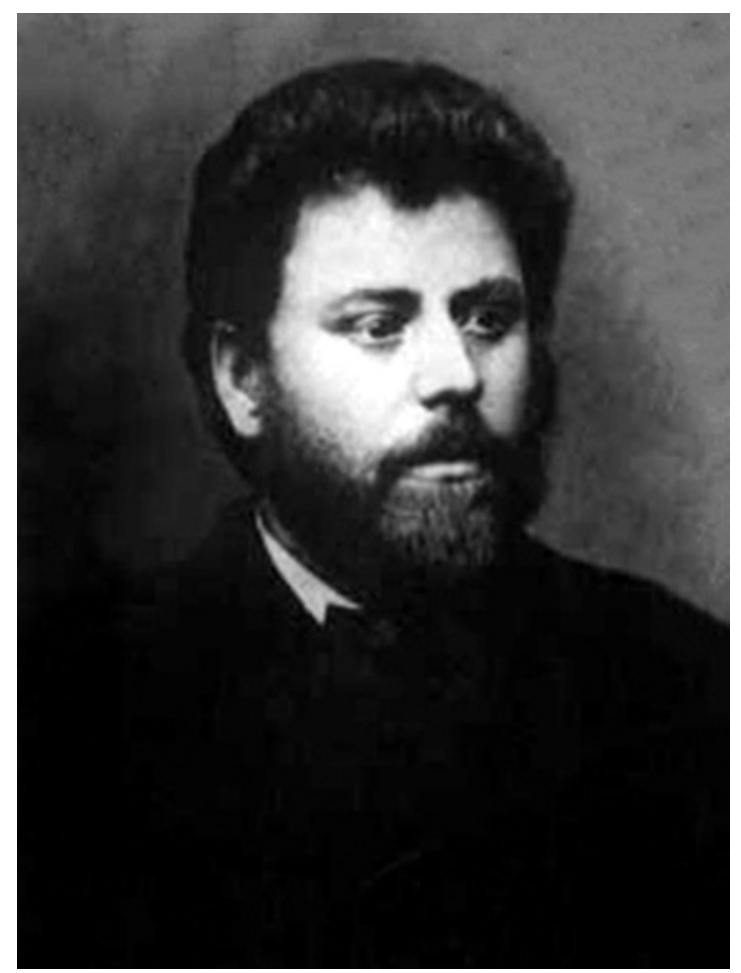

FIGURE 8.7 Creangă in a more modern portrait, as 'writer.'

club where lesser scholars and functionaries could mix with the city's political and administrative elite. ${ }^{38}$ One of these, the university professor and critic Titu Maiorescu (1840-1917), found Creangă teaching posts and commissioned him to write school manuals for use in the new primary education system (Figure 8.7).

\section{'What Village is That?'}

Creangă's literary output-like that of Ghica-developed from producing pragmatic, didactic works, to more literary ones. In his earliest published book, a school manual entitled New Method of Reading and Writing for Use in Primary Class I (1868), he portrayed the new nation-state of Romania in a text designed for young pupils to read out in short simple sentences almost entirely in the first person and present tense. A section on "My Fatherland" illustrates the type of spatial regime fostered in this work:

\footnotetext{
38 Details on this society and its cultural-political importance in Hitchins, Rumania, 56-65.
} 


\section{My Fatherland}

I am of Romanian nationality, because my parents too are Romanians; I have a big and beautiful Romanian land, which is my fatherland. In my fatherland there are many Romanians. These Romanians are citizens of my country; they are my brothers. Romanians have a duty to love and assist one another in all their needs. I love my fellow Romanians with all my heart, but I cannot help them, for I am still small and I know not how to help them; but when I grow up and learn to read and write, then I will know.

My country is called Romania: it is composed of two big countries: one is called Wallachia, and the other Moldavia. In Romania there are many villages and market towns. In the villages live peasants, who work the land and raise cattle. I know why the peasants work the land. They produce: wheat, maize, rye, barley, oats, potatoes, buckwheat, cabbage, etc. ${ }^{39}$

This might be considered an extreme example of the 'propositional' mode of writing. ${ }^{40}$ However, even in his didactic writings, Creangă had recourse not simply to this kind of present-continuous statement, in which the pupils locate themselves rather abstractly, through enunciation, amidst the products and activities of the wider collectivity. He also adopted more sophisticated pedagogical procedures, almost certainly a result of the influence of his patron, Maiorescu. ${ }^{41}$ To this end, Creangă devised tales, proverbs and micro-narratives to socialize young school children into the problem of understanding spatial relations, which are simultaneously quite complex social relations. The following

39 I. Créngă, C. Grigorescu, G. Ienăchescu, N. Climescu, V. Recénu, A. Simionescu, Metodă nouă de scriere şi cetire pentru usulŭ clasei I primară (2nd edition, Iaşi: Tipografiea Naţională, 1868), 47.

40 Roy Harris, The Linguistics of History (Edinburgh: Edinburgh University Press, 2004) distinguishes between "representational" and "propositional" historical discourse.

41 Maiorescu had studied in Germany and had undertaken a fact-finding excursion to Prussia in 1863 to study the school system there. On his return, he spoke out against "overly complex modes of education," recommending that pupils be taught to identify thoughts and propositions; to distinguish words and syllables, subject and object, animate and inanimate objects; and learn to express their sensory experience of their environment, rather than use expensive equipment or memorize and recite generic information. Titu Maiorescu, "Sciri scolare de la 1 Septemvrie 1863 pěně la 31 Augustŭ 1864," Anuariul Institutului Vasile Lupu (scóla normală de la Trei-Ierarchi) din Iassi (Iaşi: Adolf Bermann, 1863-1864), 57 . 
example is an improvization on the character of Păcală, a stock 'fool,' hero of many a Romanian joke or anecdote: ${ }^{42}$

A merchant, travelling through various villages and towns, to buy grain, maize and other products, came one day to a bridge; and just as he was about to cross it, he saw a man taking a rest there: that man was Păcală.

The merchant — keen, like any merchant, to extract some information from him — went up to him and asked:

- My good fellow Christian, where are you from?

- Well, from our home village, replied Păcală.

- From which home village?

- Look, the one over there: right by that riverbank-pointing the merchant in the direction of a hill.

- Well; but what village is that? I know it not.

- Well! How can you not know it. It is our village, and I come from it.

- Not like that, you fool! I am asking you, that village, whose estate is it part of and how is it baptized?

- Lord! You mean you don't know that the estates are the nobleman's, and this one belongs to our sire, who lives in Bucharest? And the priest baptizes the village, in a cauldron of water, as it is written in his books. ${ }^{43}$

In contrast to most traditional 'Păcală' fables, which end with a simple moral [pildă] or adage [zicală] which aims to correct or direct the audience's behaviour, Creangă's adaptation introduces modern psychological elements: an understanding of the spatial, social and cognitive assumptions of two people encountering each other at a crossing-point, where modern commerce meets traditional community values, and outsiders and insiders struggle to reconcile their different cultural horizons.

42 On the history and variants of 'Păcală' stories in Romanian see Mihai-Alexandru Canciovici, "Prefaţa," in Sabina-Cornelia Stroescu (ed.), Snoava populară românească Volume 1 (Bucharest: Minerva, 1984), v-xlvii.

43 Ion Creangă, "Păcală," Învăţătorul copiilor, 2 (4th edition, Iaşi: Tipografiea Naţională, 1874), 49-50; reprinted in id., Opere, edited by George Călinescu (Bucharest: Editura de stat pentru literatură şi artă, 1953), 293-294. 


\section{From Pedagogy to Autobiography}

Creangăs didactic writings were extremely influential in the Romanian schooling system: his Reader became the single most widely distributed work at primary level ${ }^{44}$ while his adaptations of fables became classic tools for instilling social norms. His Amintiri din copilărie [Recollections of Childhood] are even more celebrated. First published serially—just as Ghica's letters had been-in Convorbiri literare, they were gathered into book form shortly after Creangă's death in $1890 .{ }^{45}$ As with Twain's Mississippi or Dickens's evocation of the Kent marshlands in Great Expectations, part of the appeal of Creangăs text lies in its setting, in the Moldavian village of Humuleşti, at the crossroads between the province's western pastoral uplands and its eastern plains.

The text to some extent resembles a dramatic monologue, as Creangă the narrator repeatedly contrasts his present, relatively sombre state to that of the happier, livelier child Ion-or Nică a lui Ştefan a Petrei [Peter's Stephen's Johnny], to use the formulaic name he went by as a child, following the commonly-used diminutive patronymic system of naming. The broad 'macronarrative' sketches Creangă's general process of socialization, as he moves from his mother's hearth, around his family home, to the local church school, around the village and then further afield: first in the neighbouring settlements of Broşteni and Târgu Neamţ, then catechism school in the township of Fălticeni, until finally, at the age of about sixteen, he makes the 6o-mile journey to the seminary at Socola Monastery, just outside Iaşi, to complete his priestly training. This bigger story is one of, first, alienation from the intimacy and security of home; and then of integration into a modernizing national society. ${ }^{46}$

\section{Scenes from the Past}

Although in his textbooks Creangă had paid notable attention to the geography of the new Romania, Recollections of Childhood gives relatively little attention

44 George Călinescu, Ion Creangă: Viaţa şi opera (Bucharest: Editura Minerva, 1972), 52, 72.

45 Ion Creangă, Amintiri din copilărie, in Convorbiri literare 14 (10), January 1881, 365-376; 15 (1), April 1881, 1-14; 15 (12), March 1882, 445-461; id., Scrierile, 2 (Iaşi: Tipo-litografia Goldner, 1892). I have used the critical edition, Creangă, Opere, edited by Călinescu. There are three notable English translations: Recollections, translated by Lucy Byng (London: J.M. Dent and Sons, 1930); Recollections from Childhood, translated by A.L. Lloyd (London: Lawrence and Wishart, 1956); and Memories of my Boyhood, translated by Ana Cartianu and R.C. Johnston (Bucharest: Minerva, 1978). Translating Creangă is notoriously difficult: the versions presented here are based on a mixture of the Lloyd or Cartianu-Johnston translations, with my own emendations after comparison with Călinescu's edition.

46 Mircea Vulcănescu, "Ion Creangă văzut de generaţia actuală," Gând românesc 3 (1), 1935, $1-16$ sketches a framework. 
to portraying 'national' landscape. ${ }^{47}$ Critics have often considered this to be a weakness of Creangă's style, a consequence of his allegedly "unsophisticated," peasant nature, "overcome with the urge to fabulate." ${ }^{\text {( H }}$ However, his evocations of interiors and other spaces are in fact remarkable for their carefully articulated and coordinated specificity:

Sometimes I stop and call to mind the times and the people there used to be in our neck of woods when I, dear Lord, had begun to reach early boyhood in my parents' house in the village of Humuleşti, right on the Neamţ river, a large and cheerful village split into three parts: Vatra Satului, Delenii and Bejenii-as you might say, the Heart of the Village, the Uplanders and the Strangers. And you know, even in those days Humuleşti was no dead-end village; it was an old-established settlement of free peasants, a well set-up place, with its comfortable folk and their lively lads and pretty girls who knew how to spin a dancing partner just as well as a weaving-shuttle, so that the whole village would hum with the sound of the looms from one end to the other. It had a fine church too, with priests and singers and parishioners of the kind who did their village proud. And Father Ioan, who lived at the foot of the hill, Lord God, what a velvet true heart of a man he was! It was he who made them plant all those trees in the graveyard, which was marked and bounded with a shingle-roofed fence; and what a fine little room he had built by the church-door for a school; and you should have seen how tirelessly that priest used to go round the village from house to house, accompanied by Vasile the church cantor who was also the schoolteacher, a sturdy, handsome bachelor, counselling the people to send their children to get some learning. And so a whole crowd of boys and girls gathered at the school, and I was one of them, a puny little boy, blushing and frightened of my own shadow. 49

47 This has formed the object of other studies of post-Ottoman national cultures: see e.g. Robert Shannon Peckham, National Histories, Natural States: Nationalism and the Politics of Place in Greece (London: I.B. Tauris 2001); the case of Romania awaits more detailed study, but see Valentin Nicolescu, "Nature and Identity in the Construction of the Romanian Concept of Nation," Environment and History, 20 (1), 2014, 123-141.

48 E.g. G.I. Tohăneanu, Stilul artistic al lui Ion Creangă (Bucharest: Editura ştiinţifică, 1969), 38, 114; Mihaela Mancaş, Limbajul artistic românesc modern (Bucharest: Editura Universităţii din Bucureşti, 2005), 172-190. A rare and valuable attempt to rebut the thesis of Creangă's "descriptive weakness" is Valeriu Cristea, Despre Creangă (Bucharest: Editura Litera, 1989), 100-107.

49 Creangă, Opere, 17 (Lloyd trans., 15-16; Cartianu-Johnston trans., 13-14). 
Creangăs text produces a gradation of focus, starting from the generalized notion of "our neck of the woods," then mentioning the name of the village, then situating it ("right on the Neamţ river"), then enumerating its parts, before moving on to characteristic activities (weaving, dancing), and then to individual places (the churchyard, the schoolroom), and finally to interiors, which then form the scene of more detailed incidents. ${ }^{50}$ After this opening, the Recollections move quite rapidly into 'episodic' mode, recounting scenes and adventures relating to Creangă's boyhood and schooling.

\section{The Kinetics of Socialization}

The appeal of Creangă's text lies, then, in the creation not of a typical Romantic landscape - timeless, unpeopled ${ }^{51}$ — but in places "transformed into space through cultural practices," enlivened with movement, sounds, changing interrelations between moving people, objects, buildings and wider social frames. ${ }^{52}$ Here is his account of himself running away from school in fright after being quizzed on his homework:

I made for the door, slipped out quickly, and, with no hanging about the school, took to my heels homewards! A glance over my shoulder showed me two hulking brutes coming after me. Then didn't I just start running so fast that my feet struck sparks out of the ground! I passed our house without going in, I turned left and entered the yard of one of our neighbours; from the yard I went into the stableyard, and

50 This corresponds to anthropologists' understanding of communities operating a concentric set of boundaries, creating progressively wider social arenas (the room, the house, the garden, the community, etc.), but also a centre and a margin. See Claude Lévi-Strauss, Structural Anthropology, translated by Claire Jacobson and Brooke Grundfest Schoepf (New York: Basic Books, 1963), 141-143. These complex spatial interrelations are figured in language, especially through the function known as 'deixis': Friedrich Lenz, "Introduction" to id. (ed.), Deictic Conceptualization of Space, Time and Person (Amsterdam: Benjamins, 2003), vii-xiv.

51 On Romantic landscape as atemporal and unpeopled, see Mary Louise Pratt, "Scratches on the Face of the Country; or, What Mr. Barrow Saw in the Land of the Bushmen," Critical Inquiry 12 (1), 1985, 120-121.

I draw here on Michel de Certeau's distinction between location (lieu) as a stable indication of fixed positions, and space [espace]—a "practised place [...] enlivened by the aggregation of movements taking place within it." Michel de Certeau, L'invention du quotidien, 1: Arts du faire (Paris: Gallimard, 1980), 172-173. Cf. Mieke Bal, Narratology: Introduction to the Theory of Narrative (3rd edition, Toronto: University of Toronto Press, 2007), 136-138. 
from the stableyard into the maize field, newly hoed and earthed up, with the boys after me. Before they reached me, scared out of my wits as I was, I somehow managed to burrow into the mound at the root of a maize stalk. My enemy, Nică, Costache's son, with Toader, Catinca's son, an equally repellent brute, passed by me, saying just what they were going to do to me. Surely the Lord blinded them, so that they could not find me! After a while, hearing no rustling of maize leaves, not even a hen scratching the ground, I suddenly darted out, with earth on my head, and rushed home to mother and began telling her with tears in my eyes that I would not go back to school, no, not if they were to kill me. The next day, however, the priest came to our house and settled things with father; they calmed me down and took me back to school again. ${ }^{53}$

Like most small boys, Creangă is always getting himself into, and out of, a series of smaller or larger spaces which either excite or terrify him. The scene functions not just as a comedy of incident but as a subtle allegory of the broader complications and encounters that modern socialization brings.

\section{The Ethnographic Imperfect ${ }^{54}$}

Other scenes are characterized by a strongly ethnographic attention to detail. Creangă's childhood home in Humuleşti is remembered through

the big pot in the hearth to which my mother used to tie a string with little balls of wool on it, so that the cats could play till they nearly went crazy, and the whitewashed ledge of the fireplace to which I used to cling when I first began to walk, and the stove where I hid when we boys played hide-and-seek. 55

A tavern is described as follows:

In one corner there were a few bushels of beans; in another, hemp seed; in a third corner a heap of fine apples and Rădăşeni pears that will keep

53 Creangă, Opere, 19-20 (Lloyd trans., 19; Cartianu-Johnston trans., 16-17).

54 Here I adapt the concept of the 'ethnographic present' used by anthropologists: see e.g. Johannes Fabian, Time and the Other: How Anthropology Makes Its Object (New York: Columbia University Press,1983), 6o; Roger Sanjek, "The Ethnographic Present," Man, 26 (4), 1991, 612-615.

55 Creangă, Opere, 33 (Lloyd trans., 43; Cartianu-Johnston trans., 36). 
over winter till after Easter; in the fourth, peas and broad beans divided by a wide plank and nearby some Turkish pumpkins; dried pears in a wooden tub, as sweet to the taste as figs; further on, a heap of reels of hemp and flaxthread; on the rafter, hanks of worsted and yarn dyed in every colour, for making carpets and runners. Then shelves and corner cupboards, crammed with oakum, combings and other bits and bobs, as was usual in the house of a well-to-do farmer in those days. As soon as we were all assembled in that delightful room, the hostess closed the shutters, lit the candle, and came back in no time at all with a large earthen jug full of Odobeşti wine; and as she poured it into the glasses its bubbles shot up six inches into the air, it was so strong. ${ }^{56}$

As with the scene in the inn, the narrative moves from enumeration of objects to evocation of movement and action. A similar shift is observable in another passage describing a cobbler's workshop where Creangă and some schoolmates briefly boarded. First of all, the cobbler's house is evoked in a relatively static 'list':

benches and beds all round the walls, and one more by the stove, and they were all taken. Our host, after working the whole day through, would take it easy upon the stove, among boot-trees, shoemaker's lasts, soleextenders, a shoemaker's table, knives, sharp double-bladed knives, sleeking-steels, straps, pegs and leather gussets, needles, prongs, tongs, files, shoemaker's hammers, leather, thread, a broken plate with green vitriol, cobbler's wax and everything a cobbler might need. ${ }^{57}$

It is then 'populated' and set in motion:

With us lived Bodrângă, an old codger, shiftless but full of fun. For a little food and cheap tobacco, the kind you can buy six pounds of for a para, he did all the household tasks: he would cut wood, light the fire, carry water, sweep, and tell us tales all night long, crouching with his nose almost into the embers; or he would play on his flute, doinas that would wring your heart, and the corăbiească, the măriuţă, the horodincă, the alivenci, the ţiitură, "At the tent door," horas and other sprightly tunes that would set a fellow's feet a-tingling. We used to dance till the floorboards were

$5^{6} \quad$ Ibid., 65 (Lloyd trans., 100; Cartianu-Johnston trans., 80).

57 Ibid., 57 (Lloyd trans., 85; Cartianu-Johnston trans., 69). 
drenched and the soles flew off our boots, heel and all—for by now I had begun to wear boots. ${ }^{58}$

This movement from description to narration clearly functions as a way of 'animating' and enlivening what would otherwise be a fairly dry inventory of traditional village culture. At the same time, however, it marks the threshold of a new phase in Creangă's life- "for by now I had begun to wear boots."

While domestic interiors appear to provide clues and insights into the world of an apparently real individual, they also serve to suggest the presence of the outside world. Locally described and situated walls, gardens, rooftops, fences and windows can imply villages, cities and more distant units. ${ }^{59}$ Specific details lead to general cultural codes. ${ }^{60}$ These codes are then theatrically 'performed' to a greater or lesser degree, enabling readers to be drawn into the heart of an imagined community through devices such as monologue, conversation or epistolary exchange. This enables Creangă's Moldavian micro-experience to be not just representable but representative, as the village is understood in terms of the interactions that take place within it, turning it into a symbol of the individual's socialization and into a concentrically-graded series of communities. Most of the narrative impetus, therefore, is achieved through a transition from stasis to motion, from inside to outside spaces, from home to school, from the village to wider world.

In contrast to Ghica's text, there is actually no evocation of the 'site of remembrance,' except for a small conventional note at the end of each instalment. ${ }^{61}$ The act of recollection is portrayed as somewhat dangerous, conducive to melancholy:

\section{Ibid.}

59 Mancaş, Tablou şi acţiune, identifies this procedure in Ghica. It is a common one in nineteenth-century prose: see e.g. Michael Irwin, Picturing: Description and Illusion in the Nineteenth Century Novel (London: Allen and Unwin, 1979), 107-157; William J. Berg, The Visual Novel: Emile Zola and the Art of His Times (Philadelphia: Penn State University Press, 1992), 224-228.

6o James H. Reid, Narration and Description in the French Realist Novel (Cambridge: Cambridge University Press, 1993), 20. On Amintiri as repository of cultural codes, Ion Holban, Spaţiul memoriei (Iaşi: Editura Junimea, 1984), 181-191.

61 His patron Maiorescu had moved to Bucharest in the late 1870s; as the first part of the Amintiri is dedicated to the latter's daughter Livia, it is likely that the text was read in his house. Also, despite the romantic myth of Creangă having written all his works in his 'hovel' [bojdeucă] on the outskirts of Iaşi, the original publications were actually noted as having been composed in Bucharest between 1880 and 1881. 
False and fickle is man's thought, carrying him on the wings of a ceaseless longing that never leaves him in peace till he goes down to his grave. And woe betide the man who lets his thoughts take hold of him; the water gradually pulls him under, and from the greatest joy he suddenly plunges into the depths of sadness. ${ }^{62}$

For the same reason, however, it is considered both legitimate and therapeutic to talk of childhood, "for it alone is happy and innocent, and that is God's truth."63 This somewhat bleak and sententious outlook on the present serves as a counterpoint to the vivid, comic scenes from the past.

Creangă's general strategy of 'situated recollection' may be understood in comparison to similar developments in other literatures, where the creation of national scenes, landscapes and experiences associated with childhood memories is an established and well-studied procedure. ${ }^{64}$ The most traumatic encounters that the narrator's childhood self undergoes reveal the arbitrary and often still cruel modes of coercion used by the new institutions-the priest-teacher Father Ioan, who cruelly flogs the class sweetheart Smărăndiţă; the army recruiters, who press-gang the village teacher in front of the schoolchildren; and the series of alcoholic or otherwise dysfunctional priests, teachers and guardians into whose care he is entrusted.

On the surface, Creangă's work seems to have little to offer an analysis of 'post-Ottoman' cultures. The Ottoman suzerain is but rarely mentioned, except in an anecdote recounted by Creangă's maternal grandfather, who recollects participating in the anti-Ottoman revolt of 1821. But in the very process of summoning up the image of a bounded, self-sufficient, hard-working, Christian world, the country's Ottoman legacy is overwritten and replaced with new regimes of memory. What is 'post-Ottoman' about it, then, is not the portrayal of the imperial past, but the portrayal of the child's struggle to locate himself in a new world; it both constructs a sense of archaic, autochtonous virtue in the peasant village, and hints at the problematic incursions of the new state in attempting to socialize and control its newest resource, in the form of its children.

62 Creangă, Opere, 34 (Lloyd trans., 45; Cartianu-Johnston trans., 37).

63 Ibid. These seems to have been a fairly commonplace sentiment. Cf. one of Creangă's few antecedents in Romanian autobiography, Iraclie Porumbescu (born 1823): "In old age man lives off memories. Present times are hard, the future uncertain; happy is he who, having recollections, can relive them in his mind." Scrierile lui Iraclie Porumbescu, edited by Leonida Bodnărescu (Cernăuţi: Societatea Tipografică Bucovineană, 1898).

64 Wachtel, Battle for Childhood; Carol Singley, Adopting America: Childhood, Kinship, and National Identity in Literature (Oxford: Oxford University Press, 2011). 


\section{Conclusions}

It is clear that the appearance in a given culture of techniques for rendering 'landscapes of memory' has not merely technical but wider cultural significance. ${ }^{65}$ What Lucian Boia has said of fiction and other informal modes of cultural transmission, that they have "incomparably greater influence over the public than a historiographical masterpiece addressed to an elite readership," is surely especially true for first-person life stories, whose popularity with the general reading public has often far outstripped the academic attention accorded to them. ${ }^{66} \mathrm{~A}$ particular advantage of looking at spatial regimes in autobiographical texts is the insights they offer us into how historical discourses are not just produced, but also situated within a given social environment. Beyond drawing the reader into the fabric of everyday life, however stylized, they dramatize attitudes towards change and embed them in a memorable context, be it a broader tableau of political and technological transformation (as in the case of Ghica) or a story of a country boy's anxious encounter with imperfect public institutions (in that of Creangă). At the same time, the contrast between the two cases illustrates, as in the diversity of Ottoman examples analysed by Benjamin Fortna, that there was no single template for imagining 'modernization' and national destiny in the emerging new Romanian literary culture. ${ }^{67}$ Rather, they exemplify different strategies for capturing and representing, through the practice of literary recollection, historical attitudes and subjectivities at the time of the creation of the national state. ${ }^{68}$

\section{Bibliography}

\section{Works of Ion Ghica}

G. Chainoi (pseudonym), Dernière occupation des Principautés Danubiennes, Paris: Librairie Militaire de J. Dumaine, 1853.

Reorganisarea României, Bucharest: Stefan Rassidescu, 1861.

Ajutorul comerciantului, Bucharest: Socec, 1873 .

Scrisori către Vasile Alecsandri [Letters to Vasile Alecsandri], 1878-1886, in Opere, 1. edited by Ion Roman, vol. 1, Bucharest: Editura pentru Literatură, 1967.

\footnotetext{
65 Simon Schama, Landscape and Memory (London: HarperCollins, 1995); see the earlier Lucian Blaga, Peisaj şi amintire (Bucharest: Editura Sport-Turism, 1988).

66 Boia, History and Myth, 7.

67 Fortna, "Education and Autobiography."

68 Hartog, Régimes d'historicité.
} 
Convorbiri economice [Conversations on Economics], 1865-1876.

1. In Opere, edited by Ion Roman, vol. 2, Bucharest: Editura Minerva, 1970.

2. Extracts in Doreen Warriner (ed.) Contrasts in Emerging Societies. Readings in the Social and Economic History of South-Eastern Europe in the Nineteenth Century, London: Athlone Press, 1965, 156-158, 164-166, 188-191, translated by E.D. Tappe. Documente literare inedite, Bucharest: Editura de stat pentru literatură şi artă, 1959.

\section{Works of Ion Creangă}

with C. Grigorescu, G. Ienăchescu, N. Climescu, V. Recénu, A. Simionescu, Metodă nouă de scriere şi cetire pentru usulŭ clasei I primară, and edition, Iaşi: Tipografiea Naţională, 1868.

"Păcală," Invăţătorul copiilor, 2, 4th edition, Iaşi: Tipografiea Naţională, 1874, 49-50; reprinted in Opere, edited by G. Călinescu, Bucharest: Editura de Stat pentru Literatură şi Artă, 1953, 293-294.

\section{Amintiri din copilărie}

1. In Convorbiri literare 14 (10), January 1881, 365-376; 15 (1), April 1881, 1-14; 15 (12), March 1882, 445-461.

2. In Scrierile, 2, Iaşi: Tipo-litografia Goldner, 1892.

3. Recollections, translated by Lucy Byng, London: J.M. Dent and Sons, 1930.

4. In Opere, edited by George Călinescu, Bucharest: Editura de stat pentru literatura si arta, 1953 .

5. Recollections from Childhood, translated by A.L. Lloyd, London: Lawrence and Wishart, 1956.

6. Memories of my Boyhood, translated by Ana Cartianu and R.C. Johnston, Bucharest: Minerva, 1978.

\section{Other Primary}

"Patrie, naţionalitate, România," Popolul suveran, 1 (3), 28 iunie/1o iulie 1848.

Bodea, Cornelia (ed.), 1848 la români, 2, Bucharest, Editura ştiinţifică şi enciclopedică, 1982.

Cazimir, Ştefan (ed.), Pionierii romanului romînesc, Bucharest: Editura pentru literatură, 1962.

Heliade Rădulescu, Ion, “Chemare către folos, facere de bine şi glorie," [1843] in id., Opere, 1, edited by Dumitru Popovici (Bucharest: Fundaţia Regală pentru Literatură şi Artă, 1939-1943), 452.

Maiorescu, Titu, "Sciri scolare de la 1 Septemvrie 1863 pěně la 31 Augustŭ 1864," Anuariul Institutului Vasile Lupu (scóla normală de la Trei-Ierarchi) din Iassi, Iaşi: Adolf Bermann, 1863-1864. 
Ozanne, James William, Three years in Roumania, London: Chapman and Hall, 1878.

Porumbescu, Iraclie, Scrierile lui Iraclie Porumbescu, edited by Leonida Bodnărescu, Cernăuţi: Societatea Tipografică Bucovineană, 1898.

\section{Secondary}

Adanır, Fikret and Suraiya Faroqhi (eds), The Ottomans and the Balkans: A Discussion of Historiography, Leiden: Brill, 2002.

Anscombe, Frederick F., State, Faith and Nation in Ottoman and Post-Ottoman Lands, Cambridge: Cambridge University Press, 2014.

Bal, Mieke, Narratology: Introduction to the Theory of Narrative, 3rd edition, Toronto: University of Toronto Press, 2007.

Berg, William J. The Visual Novel: Emile Zola and the Art of His Times, Philadelphia, PA: Penn State University Press, 1992.

Blaga, Lucian, Peisaj şi amintire, Bucharest: Editura Sport-Turism, 1988.

Bodea, Cornelia, "David Urquhart, the Principalities and the Romanian National Movement," Nouvelles études d'histoire, 7, 1985, 207-230.

Boia, Lucian, History and Myth in Romanian Consciousness, translated by J.C. Brown, Budapest: Central European University Press, 2001.

Brown, L. Carl (ed.), Imperial Legacy: The Ottoman Imprint on the Balkans and the Middle East, New York: Columbia University Press, 1996.

Buchholz, Sabine and Manfred Jahn, "Space in Narrative," in David Herman, Manfred Jahn and Marie-Laure Ryan (eds), Routledge Encyclopedia of Narrative Theory, London: Routledge, 2005, 551-555.

Călinescu, George, History of Romanian Literature, translated by Leon Leviţchi, Milan: Nagard, 1988.

Călinescu, George, Ion Creangă: Viaţa şi opera, Bucharest: Editura Minerva, 1972.

Canciovici, Mihai-Alexandru, 'Prefaţă,' in Sabina-Cornelia Stroescu (ed.), Snoava populară românească, Volume 1, Bucharest: Minerva, 1984, v-xlvii.

Chakrabarty, Dipesh, "Postcoloniality and the Artifice of History: Who Speaks for Indian Pasts?" Representations, nr. 37, 1992, 1-26.

Chatman, Seymour, Narrative Structure in Fiction and Film, Ithaca, NJ: Cornell University Press, 1978.

Cristea, Valeriu, Spaţiul literaturii, Bucharest: Cartea Românească, 1979.

Cristea, Valeriu, Despre Creangă, Bucharest: Editura Litera, 1989.

Çrrakman, Asl, From the "Terror of the World" to the "Sick Man of Europe": European Images of Ottoman Empire and Society from the Sixteenth Century to the Nineteenth, New York: Peter Lang, 2002. 
de Certeau, Michel, L'invention du quotidien, 1: Arts du faire, Paris: Gallimard, 1980.

Djuvara, Neagu, Le pays roumain entre Orient et Occident: Les principautés danubiennes au début du xixe siècle, Paris: Publications Orientalistes de France, 1989.

Drace-Francis, Alex, "'Like a Member of a Free Nation, He spoke Without Shame': Foreign Travellers as a Trope in Romanian Cultural Tradition," in Corinne Fowler, Charles Forsdick and Ludmilla Kostova (eds), Travel and Ethics: Theory and Practice, Abingdon: Routledge, 2013, 183-203.

Drace-Francis, Alex, The Making of Modern Romanian Culture, London: I.B. Tauris, 2006.

Fabian, Johannes, Time and the Other: How Anthropology Makes Its Object, New York: Columbia University Press, 1983.

Fortna, Benjamin, "Education and Autobiography at the End of the Ottoman Empire," Die Welt des Islams 41 (1), 2001, 1-31.

Georgescu, Vlad, The Romanians: A History, translated by A. Bley Vroman, London: I.B. Tauris, 1991.

Harris, Roy, The Linguistics of History, Edinburgh: Edinburgh University Press, 2004.

Harsanyi, Doina and Nicolas Harsanyi, "The Discreet Charm of the Little Sister: France and Romania," East European Quarterly, 28 (2), 1994, 183-192.

Hartog, François, Régimes d'historicité: Présentisme et expériences du temps, Paris: Seuil, 2003.

Hitchins, Keith, Rumania 1866-1947, Oxford: Clarendon Press, 1994.

Holban, Ion, Spaţiul memoriei, Iaşi: Editura Junimea, 1984.

Iorga, Nicolae, Istoria presei româneşti, Bucureşti: Sindicatul ziariştilor, 1925.

Irwin, Michael, Picturing: Description and Illusion in the Nineteenth Century Novel, London: Allen and Unwin, 1979.

Jay, Martin, "Scopic regimes of modernity," in Hal Foster (ed.), Vision and Visuality, Seattle: Bay Press, 1988, 3-23.

Jianu, Angela, A Circle of Friends: Romanian Revolutionaries and Political Exile, Leiden: Brill, 2011.

Karpat, Kemal H. and Robert W. Zens (eds), Ottoman Borderlands: Issues, Personalities, and Political Changes, Madison, WI: University of Wisconsin Press, 2003.

Koselleck, Reinhart, Futures Past: On the Semantics of Historical Time, translated by Keith Tribe, Cambridge, MA: MIT Press, 1985.

Lenz, Friedrich, "Introduction" to id. (ed.), Deictic Conceptualization of Space, Time and Person, Amsterdam: Benjamins, 2003, vii-xiv.

Lévi-Strauss, Claude, Structural Anthropology, translated by Claire Jacobson and Brooke Grundfest Schoepf, New York: Basic Books, 1963.

Livingston, A.A., "Some Early Italian Parallels to the Locution 'The Sick Man of the East'," PMLA, 25, 3, 1910, 459-485. 
Majeed, Javed, Autobiography, Travel and Postnational Identity: Gandhi, Nehru and Iqbal: Narratives of Selfhood in Gandhi, Nehru and Iqbal, Basingstoke: Palgrave, 2007.

Mancaş, Mihaela, Limbajul artistic românesc modern, Bucharest: Editura Universităţii din Bucureşti, 2005.

Metz, Christian, Le signifiant imaginaire: psychanalyse et cinéma, Paris: Union générale d'éditions, 1977.

Mishkova, Diana, Balázs Trencsényi and Marja Jalava (eds), Regimes of Historicity in Southeastern and Northern Europe, 1890-1945, Basingstoke: Palgrave, 2014.

Murgescu, Mirela-Luminiţa, "Turcii otomani în manualele româneşti de istorie din secolul al XIX-lea," Caietele laboratorului de studii otomane, 1, 1990, 257-273.

Nicolescu, Valentin, "Nature and Identity in the Construction of the Romanian Concept of Nation," Environment and History, 20 (1), 2014, 123-141.

Philliou, Christine M., Biography of an Empire: Governing Ottomans in an Age of Revolution, Berkeley: University of California Press, 2011.

Piru, Elena, "Bucureştii din vremea lui Caragea în evocarea lui Ion Ghica," Studii şi cercetări de istorie literară şi folclor, 8 (3-4), 1959, 455-467.

Pratt, Mary Louise, "Scratches on the Face of the Country; or, What Mr. Barrow Saw in the Land of the Bushmen," Critical Inquiry 12 (1), 1985, 119-143.

Rachieru, Silvana, “The Turks Were not as Bad as Written in History Text Books': Acknowledging an Ottoman Legacy in Present-Day Romania," in Raymond Detrez and Barbara Segaert (eds), Europe and the Historical Legacies in the Balkans, Brussels: Peter Lang, 2008, 111-120.

Rachieru, Silvana, "Romanian National Histories after 1990: Between Description and Analysis," Romanian Journal for Society and Politics, 5 (1), 2003, 249-262.

Reid, James H., Narration and Description in the French Realist Novel, Cambridge: Cambridge University Press, 1993.

Sanjek, Roger, “The Ethnographic Present," Man, 26 (4), 1991, 6o9-628.

Schama, Simon, Landscape and Memory, London: HarperCollins, 1995.

Shannon Peckham, Robert, National Histories, Natural States: Nationalism and the Politics of Place in Greece, London: I.B. Tauris, 2001.

Sindbæk, Tea and Maximilian Hartmuth (eds), Images of Imperial Legacy: Modern Discourses on the Social and Cultural Impact of Ottoman and Habsburg Rule in Southeast Europe, Münster: LIT, 2011.

Singley, Carol, Adopting America: Childhood, Kinship, and National Identity in Literature, Oxford: Oxford University Press, 2011.

Taylor, R. Loring "Romanian Folklore and Ion Creangă's Recollections of Childhood," Children's Literature, 4, 1975, 70-79.

Todorova, Maria (ed.), Balkan Identities: Nation and Memory, London: Hurst, 2004. Tohăneanu, G.I., Stilul artistic al lui Ion Creangă, Bucharest: Editura ştiinţifică, 1969. Vârgolici, Teodor, Aspecte ale romanului românesc, Bucharest: Eminescu, 1985. 
Vucinich, Wayne "Some Aspects of the Ottoman Legacy," in Charles Jelavich and Barbara Jelavich (eds), The Balkans in Transition: Essays on the Development of Balkan Life and Politics Since the Eighteenth Century, Berkeley: University of California Press, 1963, 81-114.

Vulcănescu, Mircea, "Ion Creangă văzut de generaţia actuală," Gând românesc 3 (1), 1935, 1-16.

Wachtel, Andrew, The Battle for Childhood: Creation of a Russian Myth, Stanford, CA: Stanford University Press, 1990. 